\title{
To be or not to be co-infected
}

\author{
S Moutailler ${ }^{1}$, L Michelet ${ }^{1}$, J Chotte ${ }^{1}$, F Féménia ${ }^{1}$, E Le Naour ${ }^{1}$, M Cote ${ }^{1}$, ML Poulle ${ }^{2}$, E Vaumourin ${ }^{1,3}$, P Gasqui ${ }^{3}$, \\ G Vourc'h $h^{3}, J F$ Cosson ${ }^{4}$, D Raoult ${ }^{5}, M$ Vayssier-Taussat ${ }^{1^{*}}$ \\ From The 1st Conference on Neglected Vectors and Vector-Borne Diseases (EurNegVec): with Management \\ Committee and Working Group Meetings of the COST Action TD1303 \\ Cluj-Napoca, Romania. 8-11 April 2014
}

Ticks can transmit a large spectrum of pathogens including bacteria, viruses and parasites with a significant number of these pathogens being agents of emerging infectious diseases. In Europe, the most prevalent tick-borne disease is Lyme Borreliosis, caused by the bacteria Borrelia burgdorferi s.l. In most cases, Lyme Borreliosis is well diagnosed. However, beside these typical cases, patients bitten by ticks can be infected by many other pathogens (bacteria: Anaplasma spp., Bartonella spp., Rickettsia spp.; parasites: Babesia spp., Theileria spp.; and arboviruses: TBEV) that are more difficult to diagnose. Moreover, co-infections between several of these pathogens might also occur. Clinical surveys show that patients coinfected by several tick-borne pathogens present more severe symptoms and a longer duration of illness than those infected by a single pathogen. The overall objective of our study was to evaluate tick-borne pathogen coinfection in ticks and the consequence of those coinfections for human health.

Using the high throughput real-time PCR chip, we detected the DNA of the 37 major tick-borne pathogens in a cohort of questing adult of Ixodes ricinus ticks collected in Ardennes (France). We identified that $60 \%$ of ticks were infected by at least one pathogen and half of the infected ticks were coinfected. We then evaluated the risk for simultaneous infection of those pathogens to humans by detecting the DNA of the most prevalent tick-borne pathogens in the blood of patients bitten by ticks. Our data illustrated the importance of coinfection, and highlighted the necessity to evaluate coinfection in the context of tick-borne diseases.

\section{Authors' details}

${ }^{1}$ UMR Bipar, Enva, Anses, USC INRA, Maisons-Alfort, France. ${ }^{2}$ URCA, SFR Cap Santé-PROTAL EA3800 et CERFE, France. ${ }^{3}$ UR 346 Epidémiologie Animale,

\footnotetext{
* Correspondence: mvayssier@vet-alfort.fr
}

'UMR Bipar, Enva, Anses, USC INRA, Maisons-Alfort, France

Full list of author information is available at the end of the article
INRA, Saint-Genès Champanelle, France. ${ }^{4} \mathrm{CBGP}$, Campus International de Baillarguet, Montpellier, France. ${ }^{5}$ URMITE, Université de Médecine AixMarseille, Marseille, France.

Published: 1 April 2014

doi:10.1186/1756-3305-7-S1-015

Cite this article as: Moutailler et al:: To be or not to be co-infected. Parasites \& Vectors 2014 7(Suppl 1):015.
Submit your next manuscript to BioMed Central and take full advantage of:

- Convenient online submission

- Thorough peer review

- No space constraints or color figure charges

- Immediate publication on acceptance

- Inclusion in PubMed, CAS, Scopus and Google Scholar

- Research which is freely available for redistribution
C Biomed Central

(c) 2014 Moutailler et al.; licensee BioMed Central Ltd. This is an Open Access article distributed under the terms of the Creative Commons Attribution License (http://creativecommons.org/licenses/by/4.0), which permits unrestricted use, distribution, and reproduction in any medium, provided the original work is properly cited. The Creative Commons Public Domain Dedication waiver (http://creativecommons.org/publicdomain/zero/1.0/) applies to the data made available in this article, unless otherwise stated. 